\title{
Menjadikan Para Siswa Aktif Bertanya dalam Kegiatan Pembelajaran Berdasarkan Kurikulum 2013
}

\author{
Mohammad Tohir \\ Mahasiswa Program Pascasarjana Universitas Jember, Indonesia \\ matematohir@gmail.com
}

Penerapakan Kurikulum 2013 telah resmi diluncurkan oleh Pemerintah sejak tahun 2013. Beberapa sekolah telah dijadikan sekolah sasaran dan para Guru yang bersangkutan telah diikutkan pelatihan. Bahkan buku-buku pegangan siswa dan guru sudah beberapa kali direvisi sejak tahun 2014 sampai tahun 2016 ini. Akan tetapi tidak cukup hanya sampai disitu untuk mensukseskan Kurukum 2013, salah satu yang paling pokok dalam mensukseskan Kurikulum 2013 adalah penggunaan pendekatan saintifik dalam pembelajaran. Setelah beberapa tahun terakhir ini dalam menggunakan pendekatan saintik juga mengalami kendala di lapangan, salah satu yang dikeluhkan oleh para guru adalah pada bagian "kegiatan bertanya". Padahal Salah satu alasan dipilihnya pendekatan saintifik sebagai pendekatan dalam Kurikulum 2013 adalah meningkatkan kemauan dan kemampuan bertanya para siswa di kelas.

Oleh karena itu, pada kesempatan kali ini Penulis akan sedikit mengupas tentang bagaimana cara agar para siswa dapat aktif dalam melakukan kegiatan bertanya. Berikut beberapa poin penting yang harus diketahui dan dipahami oleh para Guru.

Pertama, Guru harus paham tentang Kurikulum 2013. Kurikulum 2013 dikembangkan berdasarkan berbagai alasan (Kemendikbud, 2015). Alasan-alasan tersebut antara lain: (1) Tantangan Internal, (2) Tantangan Eksternal, (3) Penyempurnaan Pola Pikir, (4) Penguatan Tata Kelola Kurikulum, (5) Penguatan Materi, (6) Karakteristik Kurikulum 2013.

Kedua, perubahan Mindset Guru (As'ari UM, 2015). Beberapa perubahan mindset yang perlu dilakukan oleh Guru antara lain adalah:

1) Guru hanya sebagai fasilitator saja dalam kegiatan pembelajaran. Guru tidak lagi dianggap sebagai satu-satunya sumber informasi dalam pembelajaran. Guru harus berubah menjadi hanya penyedia pengalaman belajar.

2) Guru tidak lagi harus menerangkan dan menjelaskan materi. Pembelajaran tidak lagi dipandang sebagai proses transfer ilmu pengetahuan kepada siswa. Pembelajaran lebih dipandang sebagai proses membantu siswa memaknai pengalaman interaksinya dengan sumber belajar.

3) Guru harus mengubah persepsinya bahwa belajar bisa berlangsung dimana saja, dan kapan saja. Guru harus memandang bahwa belajar di dalam kelas hanya sebagai salah satu saja dari sekian banyak macam kegiatan belajar lainnya.

4) Guru harus mengubah persepsinya bahwa pembelajaran bukan lagi untuk menumpuknumpuk pengetahuan. Pembelajaran harus dipandang sebagai upaya untuk mengembangkan kemampuan berpikir siswa (kritis, kreatif, dan self regulatif).

5) Guru harus berubah dari pembelajaran yang menekankan kepada kecepatan dan ketepatan berhitung, menjadi pembelajaran yang mengembangkan kemampuan merumuskan masalah.

6) Guru harus berubah dari menekankan pembelajaran yang bersifat individualistis, menjadi pembelajaran yang mendukung tumbuh berkembangnya kemauan dan kemampuan bekerjasama.

7) Guru harus mengubah persepsinya bahwa pekerjaan mengajar itu tidak lagi dominasi dirinya, tetapi siapa saja bisa menjadi guru. 
Ketiga, Guru paham tentang Pendekatan saintifik dalam pembelajaran. Pendekatan pembelajaran yang disarankan dalam kurikulum 2013 adalah pendekatan saintifik yang dikenal dengan $5 M$ (Mengamati, Menanya, Menggali Informasi, Mengasosiasi, dan Mengkomunikasikan). Berikut beberapa hal yang perlu mendapatkan perhatian kita bersama.

Keempat, Guru mampu menggunakan atau membuat Kegiatan Pengamatan. Guru dapat menggunakan kegiatan pembelajaran yang telah ada pada buku paket atau Guru dapat membuat Kegiatan Pengamatan berdasarkan kondisi sekolahnya masing-masing. Mengamati pada dasarnya adalah kegiatan memperhatikan sesuatu, dengan menggunakan indera, secara cermat. Mengamati dapat dilakukan dengan cara membaca, mendengar, menyimak, melihat (tanpa atau dengan alat) objek-objek matematika tertentu terkait masalah atau topik kegiatan. Hasil pengamatan dapat berupa definisi, aksioma, postulat, teorema, sifat, grafik dan lain sebagainya. Pengalaman belajar mengamati ini diharapkan dapat memfasilitasi siswa dalam mengembangkan dan melatih kesungguhan, ketelitian, dan kemampuan mencari informasi.

Kelima, Guru harus mendorong siswa mau dan mampu bertanya, terutama mengajukan pertanyaan yang bersifat investigatif (pertanyaan yang mendorong orang yang ditanya untuk melakukan eksplorasi terlebih dahulu sebelum menjawabnya). Pada fase menanya ini, yang perlu membuat pertanyaan adalah siswa, bukan gurunya. Berikut sembilan hal yang dapat Guru lakukan dalam kegiatan bertanya:

1) Mengenalkan suatu fenomena menarik yang belum pernah dikenali oleh siswa sebelumnya. Seperti yang telah diuraikan pada point keempat, bahwa Guru manpu membuat Kegiatan Pengamatan. Artinya adalah siswa akan mengajukan pertanyaan jikalau yang diamati itu benar-benar manarik dan membuat siswa penasaran terhadap apa yang diamati.

2) Words in a question. Siswa diberi beberapa kata atau rangkaian kata, dan mereka diminta untuk membuat kalimat yang memuat kata-kata tersebut. Misalnya Buatlah pertanyaan yang memuat kata-kata "sisi panjang" dan "sisi pendek". Buatlah pertanyaan yang memuat kata-kata "Keliling" atau "Luas".

3) Guru memberikan contoh pertanyaan pancingan, misalkan apa yang harus diperhatikan pada sisi pendek dan sisi panjang? Bagaimana cara menemukan rumus keliling dan rumus Luas persegi panjang?.

4) Guru membentuk kelompok belajar dalam kegiatan pengamatan dan bertanya. Setelah waktu pengamatan selesai, setiap siswa dalam satu kelompok wajib membuat minimal satu pertanyaan. Kemudian dipilih tiga pertanyaan yang paling bagus menurut kelompoknya. Setelah itu, tukarkan tiga pertanyaan tersebut dengan kelompok lain. Kemudian jawablah dan diskusikan tiga pertanyaan dari kelompok lain tersebut dalam kelompok masing-masing.

5) Guru dapat juga meminta siswa untuk bekerja dalam kelompok untuk membuat beberapa pertanyaan terlebih dahulu, dan selanjutnya meminta mereka bersepakat untuk memilih satu pertanyaan tertentu yang layak ditindak lanjuti dengan penyelidikan, baik oleh kelompok lain atau kelompok itu sendiri.

6) Guru memberikan kesempatan kepada setiap siswa untuk melakukan kegiatan pengamatan. Kemudian setiap siswa wajib membuta minimal tiga pertanyaan. Dalam fase ini guru mendatangi setiap siswa yang kelihatannya kesulitan untuk membuat pertanyaan, kemudian Guru mengarahkan siswa tersebut untuk mengamati kembali pada bahan kegiatan pengamatan. Sesekali Guru berperan "pura-pura" tidak tau sehingga menanyakan sesuatu kepada siswa tersebut, "kenapa kok bisa begini ya?", "bagaimana kalau menurut ananda" dan sebagainya. 
7) Completing What if or What if not questions. Siswa diberi tugas untuk melengkapi pertanyaan yang dimulai dengan kata-kata What if yang berarti "Bagaimana kalau" atau kata What if not yang berarti "bagaimana kalau tidak".

8) Questioning Breakfast. Sarapan pagi "menanya". Setiap pagi, sebelum dimulai pelajaran, siswa diminta untuk menuliskan pertanyaan. Guru bisa mengondisikan agar pertanyaan yang dibuat siswa sesuai dengan tema dan KD yang sedang dibahas.

9) Questioning Appraisal. Pemberian penghargaan kepada siswa yang memiliki kuantitas dan kualitas pertanyaan investigatif yang baik. Dengan begitu, siswa mempersepsi kegiatan menanya sebagai suatu kegiatan yang bermanfaat,

Keenam, Guru perlu memahami model-model pembelajaran yang dapat mendukung dalam penerapan pendekatan saintifik. Model pembelajaran yang mendukung penerapan pendekatan sintifik diantaranya adalah model pembelajaran Berbasis Penemuan (Discovery Learning), Model Pembelajaran Berbasis Masalah (Problem Based Learning), dan Model Pembelajaran Berbasis Projek (Project Based Learning).

\section{Citation:}

Tohir, Mohammad. (2016). Menjadikan Para Siswa Aktif Bertanya dalam Kegiatan Pembelajaran Berdasarkan Kurikulum 2013. Jember: Program Pascasarjana Universitas Jember. Tersedia Online: http://pasca.unej.ac.id/menjadikan-para-siswa-aktif-bertanyadalam-kegiatan-pembelaran-berdasarkan-kurikulum-2013/ [13 April 2016]

\section{Daftar Pustaka}

As'ari, A. R. (2014). Ideas for developing critical thinking at primary school level. In International Seminar on Addressing Higher Order Thinking: University of Muhammadiyah Makasar.

As'ari, A. R. (2015). Mewujudkan Pendekatan Saintifik dalam Kelas Matematika. In Makalah dalam Seminar Nasional Pendidikan Matematika di Universitas Jember.

Kemendikbud. (2015). Materi Pelatihan Guru Implementasi Kurikulum 2013 Jenjang SMP Tahun 2015. Jakarta: Kementerian Pendidikan dan Kebdayaan.

Tohir, Mohammad. (2014). Analisis Penerapan Kegiatan Pengamatan Buku Siswa Matematika SMP/MTs Kelas VIII Semester 1 Kurikulum 2013 di SMP Islam Sabilillah Malang. SMP Islam Sabilillah Malang.

Tohir, Mohammad. (2016). Penerapan Pendekatan Saintifik pada Pembelajaran Matematika Ditinjau dari Sikap Kritis Siswa Kelas VIII MTs Raudlatul Hasanah Pamekasan. MTs Raudlatul Hasanah Pamekasan.

Tohir, Mohammad. (2016). Peningkatan Kemampuan Guru dalam Mengimplementasikan Kurikulum 2013 di MTs Raudlatul Hasanah Pamekasan. Yayasan Pendidikan Islam AlHasanah. 